the process. Therefore do not dismiss this as the sketch of a fancy battle. Watch for yourselves; place within the pipe at the back of the mouth some fine filaments of cotton, or fluff. or down; advance them from the interior to the inner edge of the windway, and you will see them shot with energy not upward into the pipe, but outward full in your face with an unmistakeable trajectory. Do we not bring into activity the same force, "suction by velocity," when we blow through one little tube over another tube leading down to a well of perfume and draw up thereby scent-Iaden globules caught in the belt of wind passing over the tube's orifice, dispersing fine odour-sprays into the atmosphere? When a train of carriages loosely coupled is starting out of a railway station, should the engine suddenly back a little we see the hindermost portion of the train with its acquired momentum meeting the foremost portion advancing to it with reversed direction of impetus, and the central carriages receive a double compression, a rude kind of node is thus formed starting a reaction of bufferage in opposite directions; so when trains come into collision or are suddenly stopped in career, the distribution of weight, the gradients and relative velocities determine which portion feels most the influcnce of the shock. Again an analogy. There is a country custom, when the bees swarm to dredge them with flour as a means of identification, if the flour trarels you will know the bees have journeyed likewise. Take a piece of white tissue paper (a banknote answers it admirably), fold it so that a portion will occupy very nearly the space of the embouchure of the diapason pipe, by using a card it may be held level on the outer edge of the windway, it is in fact a paper reed but flaccid and inanimate; as you advance it to the windway no sooner is it caught in the current than it darts upright and becomes incorporated with the air-reed,

"Grows with its growth and strengthens with its strength."

This same crisp little bit of paper will reveal to your eyes the treasured secret of the organ-pipe, tell you how its wealth of varied tone is wrought, show you its fine arcs of flexure, how it bends less for its inward than for its outward stroke, and how its free curves are moulded to your will ; listen, and you shall hear the domestic wrangle of the reed and pipe; look, and you shall witness how in its high caprice it transmutes in a flash to harmonic speed and leaps exultant to its octave. Truly an Ariel imprisoned, endowed with form, and clothed with a white vesture making it in all its motion visible as bees.

On the supposition that the theory herein advanced is justifiable, the work of the aeroplastic reed is to be considered, specifically, to abstract. By reason of abstraction rarefaction ensues, condensation correlates therewith, the latter springing out of the former, and the product is vibration. The reed is the generator of the power and the node is the fulcrum of vibration, the place of reaction, with this peculiarity that it affords an elastic fulcrum sensitive to the encroaches of the column of air above it ; in the stopped pipe on the contrary there is a stable unyielding fulcrum, and the results of this difference are very remarkable, as will be seen in arother paper necessary to complete this exposition, but at present $I$ can only allude in passing to one of these results which it seems desirable not to omit here. Admilting my affurmations so far as they can be proved by other eyes, objections will be taken to the imaginary description of the action of air-particles and waves in the interior of the pipe, as opposed to received doctrine. Novelty is often held to bs outrage. It is an essential feature of my hypothesis that the initial movement, or preluie to vibration in the pipe, is distinct from successive movements both in its course and character; it extends throughout the pipe, is continuous but diminishing in degree, and is without a node, which is only fully established at the second course. Without entering now into further details it is important to notice that this interval between the first effurt or gasp of the pipe and the full possession of its power, is clistinctly perceived by the ear. All musicians acquainted with organs are conscious of this, and it is matter of usual comment with them how that stopped pipes are on the contrary remarkably quick of speech, instantaneous in articulation. They feel this $\mathrm{x}$ ithout reasoning of why or wherefore. As in stopped pipes there is no supernodal column, no requirement for an effort similar to that awakening motion to perfect vibration in open organ-pipes, the verdict of the ear is in both cases consistent with and corroborative of the hypothesis. Experiments with a very peculiar pipe called the "German Gamba" will throw invaluable light on the process of tone-making in organ-pipes.

Hermann Smith

\section{The Degeneracy of Man}

WITH regard to the culture of savages in Brazil the evidence of facts will be more esteemed by $\mathrm{Mr}$. Tylor than the opinion of Dr. Martius, for Mr. Tylor has brought together a wealth of facts on the history and conditions of culture.

There is one class of facts which to my mind bears particularly on this question of the tribes of Brazil and the Amazons, and that is language.

The Kiriri and Sabuyah of Bahia as also the Ge have affinities with the Shoshoni and other dialects of the Rocky Mountains, and it is difficult to believe a language of this kind can belong to an epoch of high culture.

The dialects of the Tocautius have affinities of a like character with the Ankaras and Wun of Africa, and with that of the Akka pigmies just discovered in the Nile region.

The Purus, Coroado, and Corope of Rio Janeiro appear to belong to the Carib directly, and thereby also to Africa.

In the present state of our materials and information it is im. possible to define exactly the members of each class. Thus the two groups last mentioned appear to be connected by the Baniwa and the Carib.

The main body of the population of Guarani, Tupi, Omagua, have by me been long since pointed out as having a language similar in roots and grammar to the Agaw of the Nile region. This is the highest development of language known tome in Brazil.

If the tribes of Brazil have fallen from a higher estate it is strange they should have become endowed with languages of the Prehistoric epoch.

June 29

THE gradual degeneracy of savage man from a higher type is a fact which an eminent author states in his letter in NATUR (vol. x. p. I46) to be difficult of belief. He wonders that Dr. Martius should say " the Americans are not a wild race, they are a race run wild and degraded."

The following facts seem to me to support the view held by Dr. Martius, Alex. von Humboldt, Abp. Whately, the Duke of Argyll, and others.

In the Ilium now laid bare by Tr. Schliemann, the lower strata contain more copper and fewer stone implements than the upper. "In other words, we have the very 'unscientific' fact of an 'age of stone' above an 'age of copper'" (Quart. Rev., April I874). "The newly opened mound of Hissarlik stands as a lasting witness to a progressive decay of civilisation, industry, and wealth, among the successive races of its inlabitants" (Quart. Rev.).

Among the forest tribes of Braz 1 Dr. Martius found traces of the village community with its tribe-land common to all, while huts and patches of tilled ground were treated as acquired pro. perty, the recognised owners not being individuals but families. This may be well explained as a custom brought by Asiatic immigrants into the American continent. The Chinese anciently divided the land of a viliage into nine parts. The division was made by two perpendicular and two horizontal parallel lines. The middle square was common land. The eight remaining squares were assigned to eight heads of families, who cultivated the common square, giving the produce to the Government: they constituted a village. This principle of revenue collecticn based on land distribution existed for many centuries in ancient China, and was afterwards changed for a grain tax in kind about the time of the building of the Great Wall. Agricultural emigrants to America at any date before 200 B.C. would be familiar with this mode of doing things, and would naturally carry with them the knowledge of this and other customs existing at the time in eastern Asia. The appearance of a principle of land distribution resembling that of the old Teutons, amorg American tribes, cannot then be taken as proof that they were progressing and not degenerating, for it may, when our knowledge of ancient America becomes more accurate, be seen to be one of the lingering remains of an older civilisation which in a tropical climate favourable to incio. lence would easily decline. The religious beliefs and social customs of Asiatic and American races are in many respects so similar that there is abundant ground for questioning the originality of any civilised custom found among American tribes. Why should not comparative ethnology one day find the key to solve all such questions?

This fact, looked at from the eastern Astatic point of view, is so far then from supporting the theory of progressive develop. ment, that it may rather be used as an additional buttress for the theory of degeneracy. 